\title{
ANALISIS PENGEMBANGAN KARIR DAN MOTIVASI TERHADAP KINERJA GURU DENGAN KEPUASAN KERJA SEBAGAI VARIABEL INTERVENING (Studi Kasus Pada SMK Negeri 13 Malang Jawa Timur)
}

\author{
Fathurrahman Alfa \\ Mahasiswa Magister Manajemen Program Pascasarjana Universitas Islam Malang \\ Email : fathurrahmanalfa88@gmail.com
}

\begin{abstract}
Abstrak
Manajemen sumber daya manusia adalah rangkaian strategi, proses dan aktivitas yang didesain untuk menunjang tujuan organisasi/perusahaan, lembaga pendidikan dan individu. Lembaga Pendidikan merupakan sebuah upaya untuk meningkatkan sumber daya manusia yang berkualitas. Oleh karena itu setiap proses pendidikan terus dibangun dan dikembangkan agar proses pelaksanaanya menghasilkan sesuai yang diharapkan. Tujuan penelitian ini yaitu 1) Untuk mengetahui dan menganalisis pengaruh pengembangan karir terhadap kinerja guru di SMK Negeri 13 Malang 2) Untuk mengetahui dan menganalisis pengaruh motivasi terhadap kinerja guru di SMK Negeri 13 Malang 3) Untuk mengetahui dan menganalisis pengaruh kepuasan kerja terhadap kinerja guru di SMK Negeri 13 Malang 4) Untuk mengetahui dan menganalisis pengaruh pengembangan karir terhadap kinerja guru melalui kepuasan kerja di SMK Negeri 13 Malang 5) Untuk mengetahui dan menganalisis pengaruh motivasi terhadap kinerja guru melalui kepuasan kerja di SMK Negeri 13 Malang. Populasi dalam penelitian ini adalah seluruh guru di SMK Negeri 13 Malang yang berjumlah 56 guru, mereka adalah orang-orang yang bekerja dibawah kepemimpinan Dra. Dwi Lestari, M.M selaku Kepala Sekolah di SMK Negeri 13 Malang dengan jumlah responden yaitu sebanyak 56 guru, dengan teknik analisis data menggunakan analisis path.

Berdasarkan hasil penelitian dan pembahasan yang telah dilakukan maka dapat ditarik kesimpulan sebagai berikut : 1) Pengembangan karier mempunyai pengaruh dalam upaya meningkatkan kinerja yang lebih baik. Pengembangan karier memberikan keuntungan bagi guru maupun sekolah atau organisasi. Bagi guru pengembangan karier dapat meningkatkan potensi diri sehingga terbentuk kualitas sumber daya manusia (guru), sehingga terwujudlah moral yang dapat meningkatkan semangat kerja. 2) Adanya peningkatan motivasi kerja maka kinerja guru akan mengalami peningkatan. 3) Kepuasan kerja sangat berpengaruh terhadap kinerja guru, karena semakin tidak puas nya guru terhadap suatu sekolah maka akan semakin mendorong penurunan kualitas seorang guru, penurunan itu secara langsung dapat berimbas pada proses belajar mengajar dan kondisi sekolah, sebaliknya semakin tinggi tingkat kepuasan guru terhadap sekolah berupa gaji sesuai, pekerjaan yang menarik, kesempatan promosi dan rekan kerja yang bersahabat, maka kinerja guru yang dihasilkan akan maksimal. Hasil perhitungan total effect ini menunjukkan pengaruh pengembangan karir terhadap kinerja guru melalui kepuasan kerja di SMK Negeri 13 Malang. Mengingat pengembangan karir dan motivasi dan kepuasan kerja memiliki kontribusi yang besar terhadap kinerja guru maka sebaiknya Kepala Sekolah memperhatikan hal tersebut.
\end{abstract}

Kata kunci : Pengembangan Karir, Motivasi, Kinerja Guru dan Kepuasan Kerja 


\begin{abstract}
Human resource management is a network of strategies, processes and activities designed to support the goals of organizations / companies, educational institutions and individuals. The Board of Education is an effort to improve quality human resources. Therefore, every education process continues to be built and developed so that its implementation process results as expected. The purpose of this study is to know and analyze the influence of career development on the performance of teachers in SMK Negeri 13 Malang 2) To know and analyze the motivation influence to the performance of teachers at SMK Negeri 13 Malang 3) To know and analyze the influence of job satisfaction on teachers' SMK Negeri 13 Malang 4) To know and analyze the influence of career development on teachers' achievement through job satisfaction at SMK Negeri 13 Malang 5) To know and analyze the influence of motivation to teacher performance through job satisfaction at SMK Negeri 13 Malang. The population in this research is all teachers in SMK Negeri 13 Malang which consist of 56 teachers, they are people who work under the leadership of Drs. Dwi Lestari, M.M as Principal at SMK Negeri 13 Malang with 56 respondents, with the analysis of data using path analysis.

Based on the results of the research and discussion that has been done it can be concluded as follows: 1) Career development has an influence in order to improve performance. Career development benefits teachers and schools or organizations. For career development teachers can enhance the potential of self so that the quality of human resources (teachers) is formed, so that morality can improve morale. 2) There is increasing motivation of work so the teacher's achievement will increase. 3) Job satisfaction is very influential to teacher performance, because the teacher is not satisfied with the school, it will further increase the quality of a teacher, the decrease can directly affect the learning process and the school situation, but the higher the teacher satisfaction level in the form of appropriate pay, interesting work, promotional opportunities and friendly colleagues, the performance of the teacher will be maximum. Result of total effect calculation show influence of career development to teacher achievement through job satisfaction at SMK Negeri 13 Malang. Given that career development and motivation and job satisfaction have a huge contribution to the performance of the teacher, then the Principal should consider that.
\end{abstract}

Keyword : Career Development, Motivation, Teacher Achievement and Job Satisfaction

\title{
PENDAHULUAN
}

Pendidikan yang berkualitas merupakan pondasi untuk mencetak sumber daya manusia yang sesuai dengan perkembangan masyarakat dan kebutuhan pembangunan. Lembaga pendidikan merupakan salah satu organisasi yang menghimpun guru untuk menjalankan kegiatan proses pembelajaran di sekolah. Hampir di semua lembaga pendidikan kejuruan mempunyai tujuan yaitu menciptakan lulusan yang berkualitas dan terampil dalam memenuhi kebutuhan dunia industri. Karakteristik lulusan yang baik mensyaratkan proses belajar mengajar yang baik. Oleh karena itu dibutuhkan tenaga pendidik (guru) profesional. guru merupakan aset yang paling penting dalam lembaga pendidikan karena guru memiliki peranan sebagai subyek pelaksanaan kebijakan dan kegiatan proses belajar mengajar di sekolah. Setiap lembaga pendidikan haruslah memperhatikan dan memberdayakan sumber daya manusia yang dimilikinya dengan baik agar sekolah dapat berkembang. 
Pengembangan karir adalah suatu usaha manusia yang memaksimalkan segala potensi diri untuk mendapatkan kedudukan yang lebih dari sebelumnya. Pengembangan karir adalah proses peningkatan kemampuan kerja individu yang dicapai dalam rangka mencapai karir yang diinginkan (Rivai, 2013).

Motivasi kerja adalah kondisi yang berpengaruh membangkitkan, mengarahkan dan memlihara perilaku yang berhubungan dengan lingkungan kerja (Mangkunegara, 2008).

Kinerja (prestasi kerja) adalah hasil kerja secara kualitas dan kuantitas yang dicapai oleh seseorang pegawai dalam melaksanakan tugasnya sesuai dengan tanggung jawab yang diberikan kepadanya. (Mangkunegara, 2013).

Kepuasan kerja adalah keadaan emosional yang menyenangkan atau tidak menyenangkan bagi karyawan memandang pekerjaan mereka. (Sutrisno, 2009).

Tujuan Penelitian ini adalah untuk mengetahui dan menganalisi pengaruh:

1. Pengembangan karir terhadap kinerja guru di SMK Negeri 13 Malang.

2. Motivasi terhadap kinerja guru di SMK Negeri 13 Malang.

3. Kepuasan kerja terhadap kinerja guru di SMK Negeri 13 Malang

4. Pengembangan karir terhadap kinerja guru melalui kepuasan kerja di SMK Negeri 13 Malang

5. Motivasi terhadap kinerja guru melalui kepuasan kerja di SMK Negeri 13 Malang

\section{KAJIAN TEORI \\ Pengembangan Karir}

Rivai (2013) pengembangan karir adalah proses peningkatan kemampuan kerja individu yang dicapai dalam rangka mencapai karir yang diinginkan. Yuniarsi dan Suwatno (2008) Pengembangan karir merupakan pendekatan formal yang dilakukan organisasi untuk menjamin bahwa pegawai dengan kualifikasi tepat dan berpengalaman tersedia pada saat dibutuhkan dan pengembangan karir adalah hasil dari interaksi antara karir individu dengan proses manajemen karir organisasi. Dapat disimpulkan pengembangan karir merupakan suatu proses dalam peningkatan dan penambahan kemampuan seseorang karyawan yang dilakukan secara formal dan berkelanjutan untuk mencapai sasaran dan tujuan karirnya.

\section{Motivasi kerja}

Mangkunegara (2013) motivasi kerja adalah kondisi yang berpengaruh membangkitkan, mengarahkan dan memlihara perilaku yang berhubungan dengan lingkungan kerja. sutrisno (2009) motivasi merupakan suatu faktor yang mendorong seseorang untuk melakukan suatu aktivitas tertentu. Dapat disimpulkan motivasi kerja merupakan faktor pendorong perilaku seseorang untuk melakukan suatu aktivitas tertentu yang berupa kebutuhan serta keinginan orang tersebut.

\section{Kinerja Guru}

Mangkunegara (2013) kinerja adalah hasil kerja secara kualitas dan kuantitas yang dicapai oleh seseorang karyawan dalam melaksanakan 
tugasnya sesuai tanggung jawab yang diberikan kepadanya. Departemen Pendidikan Nasional (2008:21) menjelaskan bahwa kinerja guru mempunyai spesifikasi tertentu. Kinerja guru dapat dilihat dan diukur berdasarkan spesifikasi kompetensi yang harus dimiliki oleh setiap guru. Dapat disimpulkan kinerja guru merupakan hasil kerja seorang guru dalam melaksanakan tugas-tugas pembelajaran yang dibebankan kepadanya yang dapat dilihat melalui kegiatan perencanaan pembelajaran, pelaksanaan pembelajaran dan tindak lanjut hasil penilaian.

\section{Kepuasan kerja}

Sutrisno (2009) Kepuasan kerja adalah keadaan emosional yang menyenangkan atau tidak menyenangkan bagi karyawan memandang pekerjaan mereka.

\section{Penelitian Terdahulu}

Eva Kris Diana Devi (2009) dengan judul Analisis Pengaruh Kepuasan kerja dan Motivasi Terhadap Karyawan dengan Komitmen Organiasional sebagai Variabel Intervining menyimpulkan bahwa terdapat hubungan positif yang signifikan antara kepuasan kerja dengan kinerja karyawan. Metode analisis yang digunakan dalam penelitian ini adalah analisis linear berganda.

Ekayadi (2015) dengan judul Pengaruh Motivasi dan Pengembangan Karir Terhadap Kepuasan Kerja Karyawan pada PT Rimbajatiraya Citrakarya. Hasil penelitian menunjukan bahwa motivasi dan pengembangan karir secara bersama-sama berpengaruh terhadap kepuasan kerja karyawan, dimana variabel yang paling berpengaruh terhadap kepuasan kerja adalah variabel pengembangan karir yaitu sebesar $85,625 \%$. Metode analisis yang digunakan dalam penelitian ini adalah analisis linear berganda.

Ria Imelda Kristianto (2015). dengan judul Analisis Pengaruh Motivasi Kerja, Pengembangan Karir dan Kepemimpinan Terhadap Kepuasan Kerja di PT Kapasari Surabaya. Hasil uji parsial menunjukan adanya pengaruh motivasi kerja dan kepemimpinan terhadap kepuasan kerja. Sedangkan, pengembangan karir secara parsial tidak mempengaruhi kepuasan kerja. Kepemimpinan adalah variabel paling dominan yang berpengaruh terhadap kepuasan kerja. Metode analisis yang digunakan dalam penelitian ini adalah analisis linear berganda.

\section{Kerangka Konseptual}

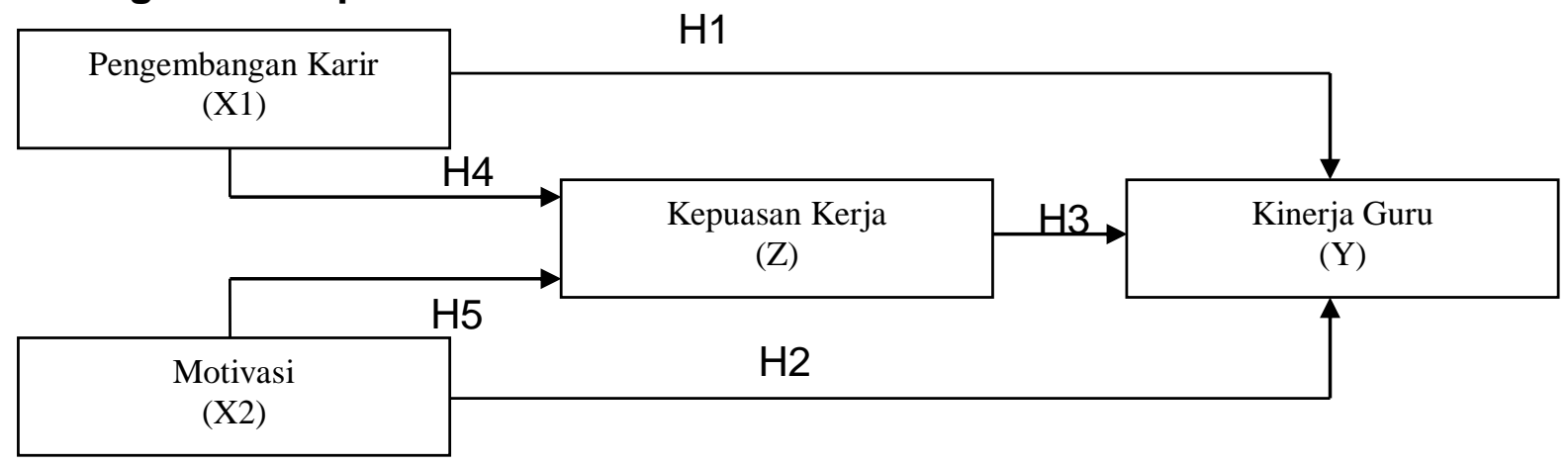

Gambar 1. Kerangka Konseptual 


\section{Hipotesis}

Hipotesis yang diajukan dalam penelitian ini adalah:

$\mathrm{H} 1$ : Bahwa ada pengaruh yang signifikan antara pengembangan karir (X1) terhadap kinerja guru (Y) di SMK Negeri 13 Malang.

$\mathrm{H} 2$ : Bahwa ada pengaruh yang signifikan antara motivasi (X2) terhadap kinerja guru (Y) di SMK Negeri 13 Malang.

H3 : Bahwa ada pengaruh yang signifikan antara Kepuasan kerja (Z) terhadap kinerja guru (Y) di SMK Negeri 13 Malang.

H4 : Bahwa ada pengaruh yang signifikan antara Pengembangan karir (X1) terhadap kinerja guru (Y) melalui kepuasan kerja (Z) di SMK Negeri 13 Malang.

H5 : Bahwa ada pengaruh yang signifikan antara Motivasi (X2) terhadap kinerja guru (Y) melalui kepuasan kerja (Z) di SMK Negeri 13 Malang.

\section{METODE PENELITIAN \\ Jenis Penelitian}

Jenis penelitian dalam penyusunan tesis ini adalah penelitian penjelasan (explanatory research), yaitu penelitian yang melakukan analisis untuk menjelaskan hubungan antar variabel dan menguji hipotesis yang telah dirumuskan sebelumnya

\section{Tempat dan Waktu Penelitian}

Penelitian ini dilaksanakan di SMK Negeri 13 Malang yang beralamat di Perum Villa Bukit Tidar Blok A2 No. 13 Kelurahan Merjosari, Kecamatan Lowokwaru, Kota Malang, Jawa Timur. Waktu pelaksanaan penelitian ini dilaksanakan pada bulan Januari 2018 sampai dengan Mei 2018.

\section{Populasi dan Sampel}

Menurut Widayat dan Amirullah (2016: 58) yang dimaksud populasi adalah: "Merupakan keseluruhan dari kumpulan elemen yang memiliki sejumlah karakteristik umum, yang terdiri dari bidang-bidang yang akan diteliti”. Populasi dalam penelitian ini adalah seluruh guru di SMK Negeri 13 Malang yang berjumlah 56 guru. Pengambilan sampel dalam penelitian ini adalah seluruh populasi yaitu 56 responden.

\section{Uji Validitas}

Ghozali (2013) Uji validitas digunakan untuk mengukur sah atau valid tidaknya suatu kuesioner. Uji validitas dapat dilakukan dengan uji pearson correlation yaitu dengan melakukan korelasi bivariat antara masing-masing skor indikator dengan total skor konstruk.

\section{Uji Reliabilitas}

Reliabilitas sebenarnya adalah alat untuk mengukur suatu kuesioner yang merupakan indikator dari variabel atau konstruk Suatu kuesioner dikatakan reliabel atau handal jika jawaban seseorang terhadap pertanyaan adalah konsisten atau stabil dari waktu ke waktu. Ghozali (2013) Instrument dapat dikatan andal (reliable) bila memiliki koefisien keandalan reliabilitas 0,06 atau lebih.

\section{Teknik Analisis Data}

Teknik analisis data yang digunakan dalam penelitian ini yaitu analisis jalur (path analysis). Analisis jalur merupakan suatu bentuk 
penerapan dari regresi berganda yang menggunakan diagram jalur sebagai petunjuk terhadap pengujian hipotesis yang kompleks. Analisis jalur (path analysis) digunakan untuk menguji sebab akibat berdasarkan pada pengetahuan, perumusan teori dan asumsi, juga dapat digunakan untuk menguji hipotesis penelitian serta menafsir hubungan tersebut. Analisis jalur ini dikembangkan sebagai suatu metode untuk mempelajari hubungan secara langsung maupun tidak langsung dari variabel independen terhadap variabel dependen.

\section{HASIL ANALISIS DATA \\ Karakteristik Responden}

Responden yang berjenis kelamin pria sebanyak $53,57 \%$, sedangkan yang berjenis kelamin wanita sebanyak 46,43 \%. Berdasarkan data ini, guru pria di SMK Negeri 13 Malang lebih banyak daripada guru wanita.

Guru yang memiliki Usia 30-40 tahun sebanyak 58,93\% dapat dikatakan bahwa sebagian besar guru memiliki usia produktif dengan harapan dapat bekerja secara maksimal di sekolah terkait dengan upaya memaksimalkan aktivitas pelaksanaan program-program yang ditetapkan oleh sekolah.

Tingkat pendidikan yang dimiliki oleh responden dalam penelitian yaitu S1 sebanyak 49 orang atau $87,5 \%$ persen. Banyaknya guru yang memiliki tingkat pendidikan sarjana (S1) menunjukkan bahwa para guru memiliki tingkat pendidikan tinggi, dengan harapan mampu melaksanakan program-program sekolah dengan kemampuan secara intelektual yang dimiliki.

Status pernikahan responden di SMK Negeri 13 Malang sebanyak $73,21 \%$ responden sudah menikah, Berdasarkan hasil tersebut maka dapat disimpulkan bahwa sebagian besar guru memiliki motivasi yang tinggi dalam bekerja dalam upaya untuk memenuhi kewajiban atau pemenuhan kebutuhan bagi keluarga.

Uji Validitas dan Reliabilitas

Tabel 1. Hasil Uji Validitas Pengembangan Karier

\begin{tabular}{|l|l|l|l|}
\hline Item & Koefisien Korelasi & r Tabel & Keterangan \\
\hline$X_{1.1}$ & 0,366 & 0,2609 & Valid \\
\hline$X_{1.2}$ & 0,387 & 0,2609 & Valid \\
\hline$X_{1.3}$ & 0,309 & 0,2609 & Valid \\
\hline$X_{1.4}$ & 0,597 & 0,2609 & Valid \\
\hline$X_{1.5}$ & 0,628 & 0,2609 & Valid \\
\hline$X_{1.6}$ & 0,323 & 0,2609 & Valid \\
\hline$X_{1.7}$ & 0,556 & 0,2609 & Valid \\
\hline$X_{1.8}$ & 0,513 & 0,2609 & Valid \\
\hline$X_{1.9}$ & 0,579 & 0,2609 & Valid \\
\hline$X_{1.10}$ & 0,479 & 0,2609 & Valid \\
\hline$X_{1.11}$ & 0,464 & 0,2609 & Valid \\
\hline$X_{1.12}$ & 0,691 & 0,2609 & Valid \\
\hline$X_{1.13}$ & 0,614 & 0,2609 & Valid \\
\hline$X_{1.14}$ & 0,527 & 0,2609 & Valid \\
\hline$X_{1.15}$ & 0,534 & 0,2609 & Valid \\
\hline$X_{1.16}$ & 0,430 & 0,2609 & Valid \\
\hline
\end{tabular}

Sumber: Data Primer Diolah Tahun 2018 
Dari Tabel 1, menunjukan bahwa instrumen pengembangan karir kerja adalah valid, karena terbukti bahwa nilai koefisien lebih besar dari nilai kritik atau tabel pada tingkat signifikan 5\%. Dengan demikian instrumen dalam penelitian ini dapat digunakan untuk menjelaskan variabel pengembangan karir pada Guru di SMK Negeri 13 Malang.

\section{Tabel 2. Hasil Uji Validitas Motivasi Kerja}

\begin{tabular}{|l|l|l|l|}
\hline Item & Koefisien Korelasi & r Tabel & Keterangan \\
\hline$X_{2.1}$ & 0,612 & 0,2609 & Valid \\
\hline$X_{2.2}$ & 0,646 & 0,2609 & Valid \\
\hline$X_{2.3}$ & 0,761 & 0,2609 & Valid \\
\hline$X_{2.4}$ & 0,739 & 0,2609 & Valid \\
\hline
\end{tabular}

Sumber: Data Primer Diolah Tahun 2018

Dari Tabel 2 menunjukan bahwa instrumen motivasi kerja adalah valid, karena terbukti bahwa nilai koefisien lebih besar dari nilai kritik atau tabel pada tingkat signifikan 5\%. Dengan demikian instrumen dalam penelitian ini dapat digunakan untuk menjelaskan variabel motivasi kerja pada Guru di SMK Negeri 13 Malang

Tabel 3. Hasil Uji Validitas Kepuasan Kerja

\begin{tabular}{|l|l|l|l|}
\hline Item & Koefisien Korelasi & r Tabel & Keterangan \\
\hline$Z_{1.1}$ & 0,846 & 0,2609 & Valid \\
\hline$Z_{1.2}$ & 0,643 & 0,2609 & Valid \\
\hline$Z_{1.3}$ & 0,608 & 0,2609 & Valid \\
\hline$Z_{1.4}$ & 0,735 & 0,2609 & Valid \\
\hline$Z_{1.5}$ & 0,403 & 0,2609 & Valid \\
\hline
\end{tabular}

Sumber: Data Primer Diolah Tahun 2018

Dari Tabel 3, menunjukan bahwa instrumen kepuasan kerja adalah valid, karena terbukti bahwa nilai koefisien lebih besar dari nilai kritik atau tabel pada tingkat signifikan 5\%. Dengan demikian instrumen dalam penelitian ini dapat digunakan untuk menjelaskan kepuasan kerja pada Guru di SMK Negeri 13 Malang.

Tabel 4. Hasil Uji Validitas Kinerja

\begin{tabular}{|l|l|l|l|}
\hline Item & Koefisien Korelasi & r Tabel & Keterangan \\
\hline$Y_{1.1}$ & 0,535 & 0,2609 & Valid \\
\hline$Y_{1.2}$ & 0,345 & 0,2609 & Valid \\
\hline$Y_{1.3}$ & 0,676 & 0,2609 & Valid \\
\hline$Y_{1.4}$ & 0,567 & 0,2609 & Valid \\
\hline$Y_{1.5}$ & 0,552 & 0,2609 & Valid \\
\hline$Y_{1.6}$ & 0,2609 & Valid \\
\hline$Y_{1.7}$ & 0,543 & 0,2609 & Valid \\
\hline$Y_{1.8}$ & 0,523 & 0,2609 & Valid \\
\hline$Y_{1.9}$ & 0,528 & 0,2609 & Valid \\
\hline$Y_{1.10}$ & 0,351 & 0,2609 & Valid \\
\hline$Y_{1.11}$ & 0,274 & 0,2609 & Valid \\
\hline$Y_{1.12}$ & 0,569 & 0,2609 & Valid \\
\hline$Y_{1.13}$ & 0,306 & 0,2609 & Valid \\
\hline$Y_{1.14}$ & 0,563 & 0,2609 & Valid \\
\hline$Y_{1.15}$ & 0,538 & 0,2609 & Valid \\
\hline$Y_{1.16}$ & 0,652 & 0,2609 & Valid \\
\hline
\end{tabular}

Sumber: Data Primer Diolah Tahun 2018 
Dari Tabel 4, menunjukan bahwa instrumen kinerja adalah valid, karena terbukti bahwa nilai koefisien lebih besar dari nilai kritik atau tabel pada tingkat signifikan $5 \%$. Dengan demikian instrumen dalam penelitian ini dapat digunakan untuk menjelaskan variabel kinerja Guru di SMK Negeri 13 Malang.

Tabel 5 . Hasil Uji Reliabilitas

\begin{tabular}{|l|l|l|}
\hline Item & Koefisien Reliabilitas & Hasil Uji \\
\hline Pengembangan karir $\left(\mathrm{X}_{1}\right)$ & 0,774 & Reliabel \\
Motivasi $\left(\mathrm{X}_{2}\right)$ & 0,632 & Reliabel \\
Kepuasan kerja $(\mathrm{Z})$ & 0,647 & Reliabel \\
Kinerja $(\mathrm{Y})$ & 0,779 & Reliabel \\
\hline
\end{tabular}

Sumber: Data Primer Diolah Tahun 2018

Berdasarkan tabel 5 hasil uji reliabilitas dapat disimpulkan bahwa seluruh variabel yang digunakan dalam penelitian ini adalah reliabel, hal tersebut dikarenakan koefisien Cronbach's Alpha diatas 0,6. Berdasarkan hasil analisis dapat disimpulkan bahwa semua instrumen dalam penelitian ini meskipun dilakukan pengujian secara berulang-ulang dapat menghasilkan hasil yang sama sehingga dapat digunakan untuk menjelaskan pengembangan karir dan motivasi terhadap kinerja guru dengan kepuasan kerja sebagai variabel intervening pada SMK Negeri 13 Malang.

\section{Hasil Uji Analisis Path (Path Analysis)}

Tabel 6. Hasil Uji Koefisien Jalur pengaruh pengembangan karir terhadap kinerja guru di SMK Negeri 13 Malang

\begin{tabular}{|l|l|l|l|l|l|}
\hline $\begin{array}{l}\text { Variabel } \\
\text { Eksogen }\end{array}$ & $\begin{array}{l}\text { Variabel } \\
\text { Endogen }\end{array}$ & Beta & $\mathbf{t}$ & Probabilitas & Keputusan \\
\hline $\begin{array}{l}\text { Pengembangan } \\
\text { Karier }\end{array}$ & Kinerja & 0,754 & 8,423 & 0,000 & Signifikan \\
\hline $\begin{array}{l}\text { Koefisien Determinasi }\left(\mathbf{R}^{2}\right) \mathbf{0 , 5 6 8}=\mathbf{5 6 , 8} \% \\
\text { N=56 }\end{array}$ \\
\hline
\end{tabular}

Dari Tabel 6, menunjukan bahwa pengaruh pengembangan karir terhadap kinerja guru di SMK Negeri 13 Malang dengan koefisien beta sebesar 0,754 , thitung sebesar 8,423 dan probabilitas sebesar 0,000 ( $p<$ $0,05)$. Probalilitas pada Tabel 4.18 dapat diketahui tingkat signifikansi kurang dari 0,5 maka keputusannya $\mathrm{H}_{0}$ ditolak. Hasil tersebut menunjukkan bahwa pengembangan karier berpengaruh terhadap kinerja Guru di SMK Negeri 13 Malang. Diketahui koefisien determinasi diperoleh nilai sebesar 0,568 , hal ini menjelaskan bahwa terdapat pengaruh yang signifikan antara pengembangan karier terhadap kinerja Guru di SMK Negeri 13 Malang dengan kontribusi sebesar 56,8\% dan pengaruh langsung sebesar 0,754. 
Tabel 7. Hasil Uji Koefisien Jalur pengaruh motivasi terhadap kinerja guru di SMK Negeri 13 Malang

\begin{tabular}{|l|l|l|l|l|l|}
\hline $\begin{array}{l}\text { Variabel } \\
\text { Eksogen }\end{array}$ & $\begin{array}{l}\text { Variabel } \\
\text { Endogen }\end{array}$ & Beta & $\mathbf{t}$ & Probabilitas & Keputusan \\
\hline Motivasi & Kinerja & 0,521 & 4,485 & 0,000 & Signifikan \\
\hline $\begin{array}{l}\text { Koefisien Determinasi }\left(\mathbf{R}^{2}\right): \mathbf{0 , 2 7 1 = 2 7 , 1 \%} \\
\mathbf{N}=\mathbf{5 6}\end{array}$ \\
\hline
\end{tabular}

Dari Tabel 7, menunjukan bahwa pengaruh antara motivasi terhadap kinerja Guru di SMK Negeri 13 Malang dengan koefisien beta sebesar 0,521 , thitung sebesar 4,485 dan probabilitas sebesar $0,000(p<0,05)$. Probalilitas pada Tabel 4.19 kurang dari 0,5 maka keputusannya $\mathrm{H}_{0}$ ditolak. Hasil tersebut menunjukkan bahwa terdapat pengaruh antara motivasi terhadap kinerja guru dan diketahui koefisien determinasi diperoleh nilai sebesar 0,271, hal ini menjelaskan bahwa terdapat pengaruh yang signifikan dari motivasi terhadap kinerja guru dengan kontribusi sebesar $27,1 \%$ dan pengaruh langsung sebesar 0,521 .

Tabel 8. Hasil Uji Koefisien Jalur pengaruh kepuasan kerja terhadap kinerja guru di SMK Negeri 13 Malang

\begin{tabular}{|l|l|l|l|l|l|}
\hline $\begin{array}{l}\text { Variabel } \\
\text { Eksogen }\end{array}$ & $\begin{array}{l}\text { Variabel } \\
\text { Endogen }\end{array}$ & Beta & $\mathbf{T}$ & Probabilitas & Keputusan \\
\hline Kepuasan kerja & Kinerja & 0,529 & 4,586 & 0,000 & Signifikan \\
\hline $\begin{array}{l}\text { Koefisien Determinasi }\left(\mathbf{R}^{2}\right): \mathbf{0 , 2 8 0}=\mathbf{2 8} \% \\
\mathbf{N}=\mathbf{5 6}\end{array}$ \\
\hline
\end{tabular}

Dari Tabel 8, menunjukan bahwa pengaruh kepuasan kerja terhadap kinerja guru di SMK Negeri 13 Malang dengan koefisien beta sebesar 0,529 , thitung sebesar 4,586 dan probabilitas sebesar $0,000(p<0,05)$. Probalilitas pada Tabel 4.20 dapat diketahui tingkat signifikansi kurang dari 0,5 maka keputusannya $\mathrm{H}_{0}$ ditolak. Hasil tersebut menunjukkan bahwa terdapat pengaruh kepuasan kerja terhadap kinerja guru di SMK Negeri 13 Malang. Diketahui koefisien determinasi diperoleh nilai sebesar 0,280, hal ini menjelaskan bahwa terdapat pengaruh kepuasan kerja terhadap kinerja guru di SMK Negeri 13 Malang dengan kontribusi sebesar 28\% dan pengaruh langsung sebesar 0,529. 
Hubungan Antar Jalur

Tabel 9 Rekapitulasi Pengaruh Langsung, Tidak Langsung dan Pengaruh Total

\begin{tabular}{|l|l|l|l|l|l|l|l|}
\hline Variabel & $\begin{array}{l}\text { Varaibel } \\
\text { Endogen }\end{array}$ & $\begin{array}{l}\text { Direct } \\
\text { Effect }\end{array}$ & $\begin{array}{l}\text { Indirect } \\
\text { Effect }\end{array}$ & $\begin{array}{l}\text { Total } \\
\text { Effect }\end{array}$ & t & Sig. & Kep. \\
\hline Pengembangan karir & Kinerja & 0,754 & - & 0,754 & 8,423 & 0,000 & Signifikan \\
\hline Motivasi & Kinerja & 0,521 & - & 0,521 & 4,485 & 0,000 & Signifikan \\
\hline Kepuasan kerja & Kinerja & 0,529 & - & 0,529 & 4,586 & 0,000 & Signifikan \\
\hline Pengembangan karir & Kepuasan kerja & 0,533 & - & 0,533 & 4,629 & 0,000 & Signifikan \\
\hline Motivasi & Kepuasan kerja & 0,627 & - & 0,627 & 5,908 & 0,000 & Signifikan \\
\hline N=56 & & & & & & & \\
\hline
\end{tabular}

Tabel 10. Rekapitulasi Pengaruh Tidak Langsung dan Pengaruh Total

\begin{tabular}{|l|l|l|l|l|l|l|}
\hline Variabel & $\begin{array}{l}\text { Variabel } \\
\text { Endogen }\end{array}$ & $\begin{array}{l}\text { Direct } \\
\text { Effect }\end{array}$ & $\begin{array}{l}\text { Indirect } \\
\text { Effect }\end{array}$ & $\begin{array}{l}\text { Total } \\
\text { Effect }\end{array}$ & Sig. & Kep. \\
\hline $\begin{array}{l}\text { Pengembangan } \\
\text { karir terhadap } \\
\text { kinerja }\end{array}$ & $\begin{array}{l}\text { Kepuasan } \\
\text { kerja }\end{array}$ & 0,754 & $\begin{array}{l}(0,533 \times 0,529) \\
=0,281\end{array}$ & $\begin{array}{l}(0,75+0,281) \\
=1,035\end{array}$ & 0,000 & Signifikan \\
\hline
\end{tabular}

Tabel 10. menunjukan perhitungan tersebut bahwa kepuasan kerja terbukti sebagai variabel intervening dalam pengaruh pengembangan karir terhadap kinerja guru melalui kepuasan kerja di SMK Negeri 13 Malang. Hasil perhitungan menunjukkan pengaruh total lebih besar dari pada pengaruh secara langsung. Hal ini dibuktikan dengan hasil perhitungan Indirect Effect (IE) yang bernilai 0,281, sedangkan pengaruh total pengembangan karir berpengaruh terhadap kinerja guru melalui kepuasan kerja di SMK Negeri 13 Malang yaitu sebesar 1,035.

Tabel 11. Rekapitulasi Pengaruh Tidak Langsung dan Pengaruh Total

\begin{tabular}{|l|l|l|l|l|l|l|}
\hline Variabel & $\begin{array}{l}\text { Variabel } \\
\text { Endogen }\end{array}$ & $\begin{array}{l}\text { Direct } \\
\text { Effect }\end{array}$ & $\begin{array}{l}\text { Indirect } \\
\text { Effect }\end{array}$ & $\begin{array}{l}\text { Total } \\
\text { Effect }\end{array}$ & Sig. & Kep. \\
\hline $\begin{array}{l}\text { Motivasi } \\
\text { terhadap } \\
\text { kinerja }\end{array}$ & $\begin{array}{l}\text { Kepuasan } \\
\text { kerja }\end{array}$ & 0,521 & $\begin{array}{l}(0,627 \times 0,529) \\
=0,331\end{array}$ & $\begin{array}{l}(0,521+0,331) \\
0,852\end{array}$ & 0,000 & Signifikan \\
\hline
\end{tabular}

Tabel 11. menunjukan perhitungan tersebut bahwa kepuasan kerja terbukti sebagai variabel intervening dalam pengaruh motivasi terhadap kinerja guru melalui kepuasan kerja di SMK Negeri 13 Malang. Hasil perhitungan menunjukkan pengaruh total lebih besar dari pada pengaruh secara langsung. Hal ini dibuktikan dengan hasil perhitungan Indirect Effect (IE) yang bernilai 0,331 , sedangkan pengaruh total motivasi terhadap kinerja guru melalui kepuasan kerja di SMK Negeri 13 Malang yaitu sebesar 0,852. 


\section{Ketepatan Model}

Ketepatan model hipotesis dari penelitian ini diukur dari hubungan koefisien determinasi $\left(R^{2}\right)$ pada kedua persamaan. Hasil model yaitu sebagai berikut:

$$
\begin{aligned}
& R^{2}=1-\left(1-R^{2} 1\right)\left(1-R^{2} 2\right) \\
& =1-(1-0,568)(1-0,271) \\
& =1-(0,432)(0,729) \\
& =1-0,315 \\
& =0,685 \text { atau } 68,5 \%
\end{aligned}
$$

Hasil perhitungan ketepatan model sebesar 68,5\% menerangkan bahwa kontribusi model untuk menjelaskan hubungan struktural dari kedua variabel yang diteliti yaitu sebesar $68,5 \%$. Sedangkan sisanya sebesar $31,5 \%$ dijelaskan oleh variabel lain yang tidak terdapat dalam model penelitian ini.

\section{PEMBAHASAN}

\section{Pengaruh pengembangan karir terhadap kinerja Guru di SMK Negeri 13 Malang}

Hasil penelitian menunjukan bahwa pengembangan karir berpengaruh signifikan terhadap kinerja guru di SMK Negeri 13 Malang. Pengembangan karir yang dilakukan sekolah yaitu meliputi peningkatan potensi diri seperti adanya pelatihan, diklat, workshop dan MGMP dan sebagainya, sehingga dengan demikian memberikan perhatian tersendiri pada karir guru akan meningkatkan moral mereka, loyalitas dan komitmen mereka pada organisasi. Bagi guru pengembangan karir dapat meningkatkan kualitas sumber daya manusia (guru), sehingga terwujudlah moral yang dapat meningkatkan semangat kerja. Apabila kondisi tersebut dapat terwujud maka secara langsung akan berdampak positif terhadap peningkatan mutu pendidikan. Hasil penelitian ini mendukung penelitian terdahulu yang dilakukan oleh dari Musa Djamaludin (2009) dan Ni Luh Putu Ariesta (2016) yang diperoleh menunjukan hasil bahwa pengembangan karier mempunyai pengaruh dalam upaya meningkatkan kinerja yang lebih baik.

\section{Pengaruh motivasi terhadap kinerja guru pada Guru di SMK Negeri 13 Malang}

Hasil penelitian menunjukan bahwa motivasi berpengaruh positif signifikan terhadap kinerja guru di SMK Negeri 13 Malang. Motivasi merupakan kondisi atau energi yang menggerakkan diri seseorang yang terarah atau tertuju untuk mencapai tujuan organisasi perusahaan. Sikap mental seseorang yang pro dan positif terhadap situasi kerja itulah yang memperkuat motivasi kerjanya untuk mencapai kinerja yang maksimal $\mathrm{Hal}$ ini sesuai dengan penelitian terdahulu yang dilakukan oleh Hakim (2014) yang berjudul "Analisis Pengaruh Gaya Kepemimpinan, Motivasi Kerja dan Kompensasi Terhadap Kinerja Guru (Studi Kasus di SMA PPMI ASSALAM Surakarta)" menunjukan bahwa adanya pengaruh yang positif dan signifikan antara motivasi kerja dengan dan kinerja guru. Hal ini 
menunjukkan bahwa motivasi kerja yang tinggi akan berpengaruh secara nyata pada tercapainya kinerja guru.

\section{Pengaruh kepuasan kerja terhadap kinerja Guru di SMK Negeri 13 Malang}

Hasil penelitian menunjukan bahwa kepuasan kerja berpengaruh positif signifikan terhadap kinerja guru di SMK Negeri 13 Malang. Hasil tersebut dapat menunjukkan bahwa dengan semakin meningkatnya kepuasan kerja guru maka kinerja juga akan mengalami peningkatan. Kepuasan kerja dapat terbentuk salah satunya dari pemberian gaji yang diperoleh guru sesuai dengan beban kerja. Hal ini akan mendorong guru untuk berusaha mencapai kinerja yang sesuai dengan tujuan yang ditetapkan oleh sekolah.

Hal ini sesuai dengan penelitian terdahulu yang dilakukan oleh oleh Kusumayani (2013) yang berjudul "Kontribusi Perilaku Kepemimpinan Kepala Sekolah, Kepuasan Kerja Guru dan Komitmen Kerja Guru Terhadap Kinerja Guru SMA Negeri di Kota Amlapura" menunjukkan bahwa adanya pengaruh positif dan signifikan antara kepuasan kerja dengan kinerja.

\section{Pengaruh Pengembangan karir terhadap kinerja guru melalui kepuasan kerja sebagai di SMK Negeri 13 Malang.}

Hasil penelitian menunjukan bahwa hasil yang didapat dalam perhitungan total effect ini menunjukkan bahwa kepuasan kerja terbukti sebagai variabel intervening dalam pengaruh pengembangan karir terhadap kinerja guru melalui kepuasan kerja di SMK Negeri 13 Malang. Hal ini dibuktikan dengan hasil perhitungan Indirect Effect (IE) yang bernilai 0,281 , sedangkan pengaruh total pengembangan karir berpengaruh terhadap kinerja guru melalui kepuasan kerja di SMK Negeri 13 Malang yaitu sebesar 1,035.

Hal ini menunjukan pengembangan karir dapat meningkatkan kinerja melalui kepuasan kerja guru dalam menjalankan kehidupan karirnya. Pengembangan karir yang berupa pengembangan potensi diri (Pelatihan, Workshop, Bimtek, MGMP dII) mampu meningkatkan kualitas sumber daya manusia serta didukung dengan penerimaan gaji dan promosi jabatan yang tepat akan dapat meningkatkan kepuasan kerja guru sehingga guru akan loyal dan berkomitmen dalam melaksanakan pekerjaannya dan dengan kepuasan kerja yang diperoleh maka guru akan meningkatkan kinerjanya pada lembaga pendidikan tersebut.

\section{Pengaruh Motivasi terhadap kinerja guru melalui kepuasan kerja sebagai di SMK Negeri 13 Malang.}

Hasil penelitian menunjukan bahwa hasil yang didapat dalam perhitungan total effect, menunjukkan bahwa kepuasan kerja terbukti sebagai variabel intervening dalam pengaruh motivasi terhadap kinerja guru melalui kepuasan kerja di SMK Negeri 13 Malang. Hal ini dibuktikan dengan hasil perhitungan Indirect Effect (IE) yang bernilai 0,331, sedangkan 
pengaruh total motivasi terhadap kinerja guru melalui kepuasan kerja di SMK Negeri 13 Malang yaitu sebesar 0,852.

Hal ini menunjukan motivasi kerja terbukti berpengaruh positif terhadap kinerja melalui kepuasan kerja guru SMK Negeri 13 Malang, Motivasi menjadi pendorong seorang guru dalam melaksanakan pekerjaan guna mendapatkan hasil yang terbaik untuk memperoleh kepuasan dalam pekerjaannya. Kinerja guru akan maksimal bila ada penghargaan dari kepala sekolah terhadap guru yang berprestasi, penerimaan kompensasi yang memadai serta pemberian kepercayaan akan tugas dan tanggung jawab yang sesuai dengan kemampuan guru. Oleh karena itulah jika guru yang mempunyai motivasi kerja yang tinggi biasanya mempunyai kepuasan kerja yang tinggi pula sehingga menghasilkan kinerja yang terbaik secara kualitas dan kuantitas sesuai dengan tanggung jawab yang diberikan kepadanya.

\section{SIMPULAN DAN SARAN}

Kesimpulan pada penelitian ini adalah :

1. Pengembangan karir berpengaruh signifikan terhadap kinerja guru di SMK Negeri 13 Malang.

2. Motivasi berpengaruh signifikan terhadap kinerja guru di SMK Negeri 13 Malang.

3. Kepuasan kerja berpengaruh signifikan terhadap kinerja guru di SMK Negeri 13 Malang.

4. Pengembangan karir berpengaruh signifikan terhadap kinerja guru melalui kepuasan kerja di SMK Negeri 13 Malang.

5. Motivasi berpengaruh signifikan terhadap kinerja guru melalui kepuasan kerja di SMK Negeri 13 Malang.

Selain ketiga variabel independent dalam penelitian ini yaitu pengembangan karir, motivasi, dan kepuasan kerja. Masih banyak faktor lain yang mempengaruhi prestasi kerja karyawan dalam bekerja. Oleh karena itu, penulis menyarankan kepada peneliti lain yang akan meneliti permasalahan yang sama, tentang kinerja karyawan agar menggunakan atau menambah variabel lain.

\section{DAFTAR PUSTAKA}

Departemen Pendidikan Nasional, "Penilaian Kinerja Guru", Direktorat Jenderal Penigkatan Mutu Pendidik dan Tenaga Kependidikan, Jakarta, 2008.

Devi, Eva Kris Diana, “Analisis Pengaruh Kepuasan Kerja Dan Motivasi Terhadap Karyawan Dengan Komitmen Organiasional Sebagai Variabel Intervining (studi pada karyawan Outsourcing Pt. Semeru Karya Buana Semarang)", Universitas Diponegoro, Semarang, 2009

Ekayadi, (2015) Pengaruh Motivasi Dan Pengembangan Karier Terhadap Kepuasan Kerja Karyawan Pada PT Rimbajatiraya Citrakarya, Fakultas Ekonomi Unviversitas Gunadarma. Jakarta. E-Jurnal Manajemen Gunadarma Vol. 6, No 5, 2015:5489-5500. 
Ghozali, I. (2013). Aplikasi Analisis Multivariate dengan program SPSS IBM SPSS 21(Edisi 7), Badan Penerbit Universitas Diponegoro, Semarang

Hakim, A. R., \& Yahya, M (2014). Analisis Pengaruh Gaya Kepemimpinan, Motivasi Kerja Dan Kompensasi Terhadap Kinerja Guru (Studi Kasus Di SMA PPMI ASSALAM Surakarta). Jurnal Pendidikan IImu Sosial, Vol.24, No 1. Surakarta : Universitas Muhammadiyah Surakarta.

Kusumayani, A., Natajaya, N., \& Atmaja, B (2013). Kontribusi Perilaku Kepemimpinan Sekolah, Kepuasan Kerja Guru Dan Komitmen Kerja Guru Terhadap Kinerja Guru SMA Neheri Di Kota Amlapura. ejournal Program Pascasarjana Universitas Pendidikan Ganesha. Bali : Universitas Pendidikan Ganesha

Mangkunegara, A. P. (2013). Manajemen Sumber Daya Manusia

Perusahaan. Cetakan kesebelas, PT Remaja Rosdakarya Offset.

Bandung:

Musa Djamaludin (2009). Pengaruh Komitmen Orgasnisasional, Pengembangan Karir, Motivasi Kerja Dan Karakteristik Individual Terhadap Kepuasan Kerja Dan Kinerja Pegawai Pemerintah Kabupaten Halmahera Timur. DIE-Jurnal IImu Ekonomi dan manajemen Vol. 5 No. 2 Januari 2009.

Ni Luh Putu A \& I Wayan Mudiartha U (2016). Pengaruh Pengembangan Karir Terhadap Kinerja Karyawan Melalui Mediasi Motivasi Kerja Pada Karya Mas ART GALLERY, E-Jurnal Manajemen Universitas Udayana Bali, Vol 5, No 9, 2016:5494-5523 ISSN : 2302-8912.

Ria, I., K. (2015). Analisis Pengaruh motivasi kerja, pengembangan karir dan kepemimpinan terhadap kepuasan kerja di PT Kapasari di Surabaya, Jurnal Hospitaly dan Manajemen Jasa, Jurnal Ekonomi \& Bisnis, 2 (3): hal: 175-193

Rivai, V., dan Sagala, E, J. Manajemen Sumber Daya Manusia untuk Perusahaan dari Teori ke Praktik. Cetakan Kelima Jakarta: Rajawali Press. 2013

Sutrisno, Edy. "Manajemen Sumber Daya Manusia”. Jakarta: Kencana, 2009.

Widayat dan Amirullah. (2016). Riset Bisnis, Edisi 1, Malang: Cahaya Press. 